\title{
Perspective
}

\section{Drugs of Abuse and the Aging Brain}

\author{
Gayathri J Dowling*,', Susan RB Weiss' and Timothy P Condon' \\ 'National Institute on Drug Abuse, NIH, DHHS, Bethesda, MD, USA
}

\begin{abstract}
Substance abuse among older adults has received little attention in the past, presumably because this population has traditionally accounted for only a small percentage of the drug abuse problem in the United States. The aging of the baby boomer generation (born 1946-1964), however, will soon swell the ranks of older adults and dramatically alter the demography of American society. Several observations suggest that this expansion will likely be accompanied by a precipitous increase in the abuse of drugs, including prescription medications and illicit substances, among older adults. While it is now evident that the brain changes continuously across life, how drugs of abuse interact with these age-related changes remains unclear. The dynamic nature of brain function, however, suggests that substance abuse during older age may augment the risks and require unique considerations for diagnosis and treatment. In addition to describing current and projected prevalence estimates of substance abuse among older adults, the present review discusses how aging affects brain systems involved in drug abuse, and explores the potential impact of drug abuse on the aging brain. Future directions for substance abuse research among older adults will also be considered.
\end{abstract}

Neuropsychopharmacology (2008) 33, 209-218; doi:I0.1038/sj.npp. I301412; published online 4 April 2007

Keywords: brain; aging; neurotoxicity; neuroprotection; neurotransmitters; addiction

\section{INTRODUCTION}

Substance abuse among older adults (ie, aged 50 years and older) has received little attention in the recent past presumably because it has traditionally represented a relatively small percentage of the substance abuse problem in the United States, which has been viewed as primarily a problem of youth. Indeed, based on data from the Federal Bureau of Narcotics indicating a sharp decline in opiate abuse after the age of 36, Winick (1962) hypothesized that a substantial majority of opiate addicts 'mature out' of their addiction as a result of the normal aging process (Winick, 1962). Subsequent findings, however, have not supported a cause-and-effect relationship between chronological age and the cessation of addiction (Rosenberg, 1995). Instead, it is now evident that addiction initiated in youth often persists into advanced age (Anderson and Levy, 2003; Rosenberg, 1995).

Several lines of evidence suggest that substance abuse among older adults is on the rise. The aging of the baby boomer generation, comprised of those born from 1946 to 1964, will soon swell the ranks of older adults to unprecedented numbers. Even if the proportion of older adults abusing drugs in coming years were to hold steady at

\footnotetext{
*Correspondence: Dr GJ Dowling, Office of Science Policy and Communications, National Institute on Drug Abuse, 600I Executive Boulevard, Room 5235, MSC 959I, Bethesda, MD 20892-959I, USA, Tel: + | 30| 443 607|, Fax: + | 30 | 4802485 ,

E-mail: dowlingg@mail.nih.gov

Received I J July 2006; revised I March 2007; accepted 5 March 2007
}

current levels, the dramatic increase in the size of this population would produce an equally dramatic increase in the absolute number of older individuals with substance abuse disorders. Given several reasons, however, it appears that the proportion of older adults abusing drugs is increasing and will continue to do so for the foreseeable future.

With major advances in medicine over the last several decades, Americans are not only living longer, but are living healthier; longer; ironically, this laudable trend is weakening one of the strongest motivations for changing addictive behavior among older adults: the declining health and increasing frailty that have typically accompanied aging. Thus, individuals advancing into their later years may feel less compelled to alter their substance abuse practices and, as a result, may prolong their drug abuse careers. Substance abuse in older adults may be further facilitated by the alleviation of longstanding family responsibilities and the availability of greater disposable income. Additionally, substance abuse may be continued or even initiated in later years as a means of coping with the profound sense of loss many older adults experience as they retire, their children leave home, and they lose loved ones.

The baby boomers have also been the first generation indoctrinated with the views, values, and expectations of the 'quick-fix' culture. Part and parcel of this indoctrination has been the rise in the promise, awareness, and dispensation of prescription medications. The widespread use and effectiveness of many prescription medications has endorsed the view that many problems, medical and otherwise, have a quick and simple fix, and that rapid remedies frequently 
come in the form of a medication. There are now more medications available to treat more maladies than ever before, and increased awareness of these medications appears to be driving increased use. For example, in 2001, $30 \%$ of Americans spoke with their physicians about medications they saw advertised, and $44 \%$ of these patients received the prescription medications they inquired about (Kaiser Family Foundation, 2003). Indeed, from 1992 to 2002 the number of prescriptions filled increased $154 \%$ (National Center on Addiction and Substance Abuse (CASA), 2005). Alarmingly, there have also been large increases in the number of emergency department (ED) mentions of nonmedical use of prescription medications. For example, the number of ED mentions for abuse of hydrocodone more than doubled from 1994 to 2001 (Substance Abuse and Mental Health Services Administration, 2002), possibly reflecting its greater availability.

Illicit substance abuse among older adults is also likely to increase as suggested by an apparent increase in the number of ED mentions for illicit drugs among this population (Substance Abuse and Mental Health Services Administration, 2002). This interpretation is consistent with projections of past year illicit drug abuse among older adults in the year 2020 (Colliver et al, 2006) and is further supported by an overall increased prevalence of illicit drug abuse among baby boomers that is persisting as this generation ages (Gfroerer $e t a l, 2003$ ). And while we now have evidence that the brain continues to change throughout life, there is little understanding of how drugs of abuse interact with these age-related changes. The dynamic nature of the brain, however, suggests that substance abuse in older adults may have unique consequences that influence drugs' effects in the brain and the treatment of substance abuse in this population.

The present review will describe the current and projected prevalence estimates of substance abuse in older adults, as well as the current understanding of how aging affects the predominant neural pathways involved in drug abuse. The potential impact of drug abuse on the aging brain will also be explored. The implications of age-related pharmacokinetic/dynamic changes and comorbid physical and mental health conditions will be considered and followed by a discussion of the unique considerations influencing the development of effective substance abuse screening and treatment programs targeted at older adults. As this is an emerging field of research, we conclude by discussing future directions for substance abuse research in this population.

\section{CURRENT AND PROJECTED DRUG ABUSE TRENDS AMONG OLDER ADULTS}

Alcohol and prescription drug abuse appear to be the main contributors to substance use disorders in adults aged 50 and older (Adams et al, 1992; Adams, 1996; Adams and Cox, 1995; Jinks and Raschko, 1990; National Center on Addiction and Substance Abuse at Columbia University (CASA), 1998; Weintraub et al, 2002; Whitcup and Miller, 1987). Indeed, according to the 2005 National Survey on Drug Use and Health, only $2.5 \%$ of this population had used illicit drugs in the past month (these data must be interpreted cautiously, however, as older adults are not well represented in the sample) (Substance Abuse and Mental Health Services, 2006).

Estimates of alcohol abuse or dependence in older adults vary greatly, from less than 1 to $26 \%$, depending on the specific age range studied, the gender ratio, the geographic location, the study setting, and the screening tools used (Adams et al, 1992; Adams, 1996; Adams and Cox, 1995). Nonetheless, alcohol is considered to be one of the most common substances of abuse for this population. Prescription drug abuse is also common among older adults. The use of prescription medications increases with age (Rathore et al, 1998), and although individuals 60 years and older comprise about $16 \%$ of the population, they account for approximately one-third of all medications prescribed in the United States (Baum et al, 1988). As the availability and accessibility of prescription medications continue to increase, it seems likely that the proportion of older adults using these drugs and experiencing substance abuseassociated problems will also rise. Complications from prescription drug use in older adults may result from either unintended 'misuse' (eg patient error, inappropriate prescribing) (Edwards and Salib, 1999; Hanlon et al, 2002) or 'abuse' in which psychotropic medications not required for treatment of a medical condition are taken intentionally. Abuse of prescription medications may also involve taking higher than prescribed doses of drugs required for management of diagnosed medical conditions, such as anxiety, sleep problems, or chronic pain. Additionally, many older individuals use over-the-counter medications (Menninger, 2002; Miller et al, 1991; Stoehr et al, 1997) and herbals/ supplements (Kales et al, 2004) which when combined with psychotherapeutic or other drugs may produce harmful drug interactions.

Whereas alcohol and prescription drugs remain the most commonly abused substances among older adults, several lines of evidence suggest that abuse of illicit drugs in this population is on the rise. A recent observational study by Schlaerth et al (2004) reported that the types of drugs used by individuals over 50 appear to mirror those used in the general population. Rather than being limited to alcohol and prescription medications, these older individuals also abused cocaine, marijuana, phencyclidine, and amphetamine as well as various drug combinations. Increasing abuse of drugs other than alcohol and prescription medications is further suggested by a rise in the number of ED mentions for illicit substances among patients 55 years and older. For example, cocaine mentions have risen $242 \%$ from 1400 mentions in 1995 to almost 5000 mentions in 2002. Similarly, heroin $(\sim 1300$ to $\sim 3400)$, marijuana $(\sim 300$ to $\sim 1700)$ and amphetamine $(\sim 70$ to $\sim 560)$ mentions have all risen during this time period (Substance Abuse and Mental Health Services Administration, 2002).

This changing pattern of drug abuse may reflect in part the aging of the baby boomer generation. Born between 1946 and 1964, baby boomers currently represent approximately $29 \%$ of the United States population. It is anticipated that by the year 2030, the aging of this generation will increase the number of persons over the age of 65 to more than 71 million, twice that in 2000 (Administration on Aging, 2003). This growth is accompanied by a history of youth drug abuse in this cohort that is significantly higher than previous older populations (Johnson and Gerstein, 
1998), a difference that is persisting as baby boomers age (Gfroerer et al, 2003) and suggesting significant increases in illicit drug abuse in this population in coming years. For example, Colliver et al (2006) used early onset drug abuse among other variables to develop models of current (past year) drug use among older adults (50 years and older) in the year 2020. By applying these models to data from the National Survey on Drug Use and Health, they predict that past year use of any illicit drug will increase from $2.2 \%$ in $1999-2001$ to $3.1 \%$ in 2020 , resulting in 3.5 million older adults having used illicit drugs in the past year, with the number of older past year marijuana users increasing 355\% from approximately 719000 in $1999-2001$ to 3.3 million in 2020 and past year nonmedical users of psychotherapeutics increasing $190 \%$ from 911000 to 2.7 million. Indeed, data from the most recent National Survey on Drug Use and Health (2006) indicate that, among adults aged 50-59, the rate of current illicit drug use increased from $2.7 \%$ in 2002 to $4.4 \%$ in 2005 (Substance Abuse and Mental Health Services, 2006). Among adults aged 55-59, the rate of current illicit drug use also increased significantly from 1.9 to $3.4 \%$. These increases reflect the contribution of the aging baby boomer generation. Increasing use of illicit drugs among older adults may also reflect the fact that people are now living longer and that as they age their patterns of drug use remain stable (Anderson and Levy, 2003; Capel and Peppers, 1978; Frank, 2000; Hser et al, 2001; Rosen, 2004).

\section{AGING EFFECTS ON THE PRIMARY NEUROTRANSMITTER SYSTEMS INVOLVED IN DRUG ABUSE}

The brain changes in a variety of ways across the lifespan (Courchesne et al, 2000; Jernigan et al, 2001; Sowell et al, 2003). How these changes alter drug-brain interactions and what implications they may have for older adults who abuse drugs, however, is poorly understood. It is possible though that the aging process itself may create a distinct set of problems unique to older substance abusers. All drugs of abuse act by altering neurotransmission in the brain, most predominantly, the dopaminergic, serotonergic, and glutamatergic systems. These systems have also been shown to change with age. For example, the number of dopaminergic cell bodies in the substantia nigra (McGeer et al, 1977) as well as levels of striatal dopamine and homovanillic acid-a dopamine metabolite - all decline with age (Haycock et al, 2003; Reeves et al, 2002). Similarly, numerous studies have shown age-related decreases in dopamine receptor binding in the striatum (Antonini et al, 1993; Antonini and Leenders, 1993; Iyo and Yamasaki, 1993; Mukherjee et al, 2002; Rinne et al, 1990; Severson et al, 1982; Suhara et al, 1991; Volkow et al, 1996; Wang et al, 1998; Wong et al, 1997) and in extrastriatal regions including the frontal cortex, anterior cingulate gyrus, temporal insula, and thalamus (Inoue et al, 2001; Kaasinen et al, 2000, 2002; Mukherjee et al, 2002; Volkow et al, 2000; Wang et al, 1996). Although not clinically significant, these reductions are associated with modest changes in motor and cognitive functions (Volkow et al, 1998a,b). Age-related decreases in dopamine receptor binding have been correlated with agelinked metabolic reductions in the frontal cortex and anterior cingulate gyrus, similar to that observed in cocaine abusers (Volkow et al, 1993, 2000), suggesting that the effects of reductions in dopamine receptor function with age may be exacerbated by drug abuse.

Dopamine transporter (DAT) binding also declines with age (Bannon and Whitty, 1997; Ishikawa et al, 1996; Kazumata et al, 1998; Kemppainen et al, 2001; Mozley et al, 1996, 1999; Pirker et al, 2000; van Dyck et al, 1995, 2002; Volkow et al, 1994). The consequences of normal reductions in DAT binding in the human brain are not known. One might hypothesize, however, that decreased DAT function could result in decreased responsiveness to drugs of abuse that interact with DAT such as amphetamine and cocaine (Bannon et al, 1992; Giros et al, 1996). For example, age-related decreases in methylphenidate-induced extracellular dopamine release may reflect reductions in DAT binding that are part of normal brain aging (Volkow et al, 2001). Interestingly, Wang et al (1997) reported that chronic cocaine abusers in their study did not exhibit agerelated reductions in DAT. Although potential confounding factors remain to be examined, this finding suggests that cocaine abuse may interfere with at least some changes in neurotransmitter activity that appear to be a normal feature of aging (Wang et al, 1997).

The glutamatergic and serotonergic systems-both of which have been implicated in substance abuse-also appear to change with age. Age-related decreases in $\mathrm{N}$ methyl-D-aspartate-type glutamate receptor density and function have been observed in most cortical areas, striatum and hippocampus (Olney et al, 1997; Segovia et al, 2001; Villares and Stavale, 2001). How the serotonergic system changes with age is less clear: several investigators have reported age-related decreases in serotonin receptor and transporter binding in various brain regions (Adams et al, 2004; Allen et al, 1983; Arranz et al, 1993; Baeken et al, 1998; Blin et al, 1993; Cheetham et al, 1988; Gross-Isseroff et al, 1990a, b; Hesse et al, 2003; Iyo and Yamasaki, 1993; Kuikka et al, 2001; Marcusson et al, 1984a,b, 1987; Pirker et al, 2000; Sparks, 1989; van Dyck et al, 2000; Yamamoto et al, 2002); however, others have reported increases or no agerelated changes (Allen et al, 1983; Andersson et al, 1992; Arranz et al, 1993; Marcusson et al, 1987; Severson et al, 1982, 1985).

The cannabinoid system is also of interest in this regard-originally identified for its role in mediating the effects of marijuana in the brain; the cannabinoid system has now been implicated in myriad functions from appetite to memory to pain, as well as reward and addiction. In the only relevant aging study we are aware of, investigators reported no differences in endocannabinoid levels or cannabinoid receptor density in old adult versus young adult mice (Wang et al, 2003). Older mice did exhibit decreased cannabinoid receptor coupling to the G-protein signaling cascade in the limbic forebrain compared to younger mice. This reduction in function was associated with decreased ethanol preference, which could be reversed by administration of a cannabinoid agonist (Wang et al, 2003), demonstrating highly specific age-related changes to a receptor system that result in decreased intake of an addictive substance.

With the exception of the study noted above, few studies of age-related changes in the brain have focused on how 
these changes affect the function of the reward system and/ or its sensitivity to drugs of abuse. And, in those that have, the results have been mixed (Hicks et al, 1980; Kilbey et al, 1980; Kilbey and Ellinwood Jr, 1977; Smith et al, 1978; Warenycia and McKenzie, 1989). Jha et al (2004) reported that the brain-stimulation reward (BSR) threshold is lower in older than in younger rats suggesting the brain reward system becomes more sensitive with age; however, the authors found no significant age differences in the effects of morphine on BSR threshold (Jha et al, 2004). On the other hand, Knapp et al (2004) found that aged rats spent significantly more time engaged in stereotypic biting behaviors following repeated administration of moderately high doses of morphine than did younger rats suggesting that sensitivity to at least some effects of opioids may increase with age.

Thus, the overall impact of age-related changes in brain structure and function on the rewarding and other effects of abused drugs is difficult to predict at this time. And, it is further complicated by an individual's past history of drug exposure, since, for example, prolonged drug abuse can itself alter the function of various brain transmitters and systems, potentially compounding the effects of aging. Whether these alterations will lead to different patterns of drug abuse due to altered responsiveness requires further investigation in both animal models and humans.

\section{EFFECTS OF DRUGS OF ABUSE ON THE AGING BRAIN}

\section{Neurotoxicity}

In addition to changes in drug responsiveness, animal studies suggest that susceptibility to drug-induced neurotoxicity may, at least in some cases, increase with age. For example, sensitivity to methamphetamine-induced toxicity has been shown to increase with age: compared with younger animals, older animals-despite lower exposure doses-show greater striatal dopamine reductions and morphological alterations as well as increased levels of glial fibrillary acid protein (Bowyer et al, 1993; Miller et al, 2000; Teuchert-Noodt and Dawirs, 1991). These changes may reflect age-related increases in drug accumulation in the brain such as occurs with amphetamine (Truex and Schmidt, 1980). Methamphetamine-induced neurotoxicity may also involve oxidative stress, which has been implicated in many age-related diseases (Barja, 2004). In one recent study, older rats exposed to methamphetamine showed increased oxidative damage, which correlated with increased methamphetamine-induced dopaminergic toxicity (Imam and Ali, 2001).

Chronic abuse of some drugs may exacerbate normal agerelated changes in the brain. For example, maturation of frontal and temporal lobe white matter between the ages of 20 and 50 appears to be arrested in chronic cocaine abusers. Thus, the natural decline in white matter volume observed after age 50 may be more dramatic in cocaine abusers than in the healthy aging population (Bartzokis et al, 2002). Similarly, the brains of cocaine-dependent subjects exhibit an increased number of age-related white matter lesions, thought to be linked to cognitive abnormalities. If so, these deficits would be more prevalent among aging addicts as compared with normal older adults (Bartzokis et al, 1999a, b).

\section{Neuroprotection}

Some drugs of abuse may also possess neuroprotective properties. For example, epidemiological studies over the past 50 years have shown that cigarette smoking, despite a multitude of adverse health effects, is associated with a lower incidence of Parkinson's disease, a neurodegenerative disorder of aging. Nicotine, in particular, has been shown to be neuroprotective in a number of in vitro and in vivo systems and through a variety of mechanisms. Other components of cigarette smoke such as those that decrease brain monoamine oxidase B activity may also contribute to a lower incidence of Parkinson's disease (Fowler et al, 1996; Quik, 2004).

Marijuana may have neuroprotective properties as well. Although epidemiological studies have not correlated marijuana abuse with decreased disease prevalence, studies have shown that components of marijuana may protect against neuronal damage caused by glutamate-mediated excitotoxicity, free radicals and reactive oxygen species, and/or pro-inflammatory cytokines (Baker et al, 2003; Croxford, 2003; Fowler, 2003; Grundy et al, 2001; Grundy, 2002; Hampson et al, 1998, 2000; Lastres-Becker et al, 2002; Panikashvili et al, 2001). Oxidative and inflammatory damage are prevalent in aging and may contribute to numerous adverse health conditions associated with aging such as ischemic stroke, Parkinson's disease, Alzheimer's disease, and cardiovascular disease (Grimble, 2003). Delta9-tetrahydrocannabinol (THC), the primary psychoactive component of marijuana, has been shown to decrease proinflammatory cytokine production. And, both THC and the nonpsychoactive marijuana constituent cannabinidiol were found to be comparable to if not more effective than standard antioxidants in preventing toxicity due to reactive oxygen species (Grundy et al, 2001; Hampson et al, 1998, 2000).

Although these drugs may have neuroprotective properties, they also have adverse health consequences that may outweigh their potential benefits. Understanding the mechanisms by which these drugs might be neuroprotective, however, may lead to the development of new, more targeted pharmacotherapies aimed at preventing and/or treating a variety of diseases associated with aging.

\section{CONSEQUENCES OF PHARMACOKINETIC/DYNAMIC CHANGES WITH AGE}

Because aging affects drug disposition and metabolism, even moderate use of alcohol, many prescription and overthe-counter medications and illicit drugs may have devastating consequences. Pharmacokinetics - the process by which a drug is absorbed, distributed, metabolized, and eliminated by the body - are known to change with age. For example, the volume of drug distribution decreases with reductions in lean body mass and total body water content. Moreover, renal drug elimination is reduced. These agerelated changes may lead to elevated drug serum levels and increased potential for adverse drug reactions. Age-related 
differences in pharmacokinetics, however, do not necessarily translate into differences in response to a drug. For example, analysis of age and opiate-induced pain relief in postoperative cancer patients found that there was no difference between young and old in maximum pain relief. However, pharmacokinetic differences due to age (ie slower clearance from the plasma) did result in a longer duration of drug action (Kornetsky, 2004).

Pharmacodynamics, such as drug-receptor interactions, receptor-membrane interactions, and postreceptor events also may change with age (Noble, 2003). For example, agedependent changes in the GABAa-benzodiazepine receptor complex may underlie older patients' heightened sensitivity to benzodiazepines and the resulting sedation, confusion, ataxia, immobility, short-term memory loss, and other cognitive disturbances. Similarly, reduced homeostatic mechanisms may lengthen the time older adult patients require to regain steady-state levels following drug therapy (Turnheim, 2003). These pharmacokinetic/dynamic changes may place older adults who abuse drugs at elevated risk for potentially severe drug-drug and drug-disease interactions.

\section{COMORBID HEALTH CONDITIONS}

Psychiatric disorders and substance abuse often co-occur in younger and older adults. Indeed, one study reported that approximately $20 \%$ of hospitalized older adult psychiatric patients had a comorbid substance abuse disorder (Whitcup and Miller, 1987). Similarly, a geriatric outpatient study found that only $7.1 \%$ of substance abusing patients did not have a comorbid psychiatric diagnosis (Holroyd and Duryee, 1997). Drug abuse may affect older adults with psychiatric disorders in a variety of ways. For example, prolonged psychotropic drug use, specifically benzodiazepines, has been associated with depression (Dealberto et al, 1997; Hogan et al, 2003) and cognitive decline in older adults (Paterniti et al, 2002). In contrast, stimulants may improve some age-related cognitive deficits (Grottick and Higgins, 2002; Halliday et al, 1986).

Additionally, the prevalence of many medical conditions increases with age and may be affected by concomitant drug abuse. For example, amphetamine and cocaine abuse often lead to cardiovascular complications such as arrhythmias and myocardial infarction in young addicts. Long-term abuse may also predispose to premature atherosclerosis, ventricular hypertrophy, and cardiomyopathy. The presence of these effects in young adults suggest that drug abuse among older individuals, in whom cardiovascular disease is more prevalent, may have even more severe consequences (Frishman et al, 2003a, b).

Similarly, illicit drug abuse has been shown to contribute to reductions in kidney function and end-stage renal disease (Perneger et al, 2001; Vupputuri et al, 2004). Indeed, the age and race-adjusted risk for mild kidney disease was three times greater among cocaine and crack users and four times greater among users of psychedelic drugs (Vupputuri et al, 2004). Thus, illicit drug abuse may also exacerbate declines in kidney function that frequently occur with increasing age. Drug abuse may also affect the onset and course of diabetes. A history of substance abuse is associated with an earlier age of onset for diabetes (Johnson et al, 2001).
Similarly, diabetic ketoacidosis (DKA), a potentially fatal complication of diabetes, has been related to cocaine abuse in $14 \%$ of adult DKA admissions, suggesting that diabetics who abuse cocaine may be more prone to developing DKA (Warner et al, 1998).

Neurological and respiratory disorders, cancer, and many other age-associated diseases may also be exacerbated by drug abuse (de Rekeneire et al, 2003; Elwan et al, 1997; Sarkisian et al, 2000). Furthermore, comorbid drug abuse likely increases the risk of accidents and falls that frequently result in hip fractures and other injuries in older individuals. How drug abuse impacts common disorders that frequently accompany aging remains poorly understood. There is, however, significant reason to believe that as the number of substance abusing older adults increases, so may the prevalence of drug-disease complications in this population.

\section{CLINICAL IMPLICATIONS}

\section{Recognizing Substance Abuse in Older Adults}

The potential for additional drug-related complications underscores the importance of recognizing and treating substance abuse in older adults. Recognizing inappropriate drug use in this population, however, can be complicated by a number of factors. For example, almost half of primary care physicians surveyed reported that they found it difficult to discuss prescription drug abuse with their patients (National Center on Addiction and Substance Abuse at Columbia University (CASA), 2000). This finding suggests that health-care professionals in the best position to identify and facilitate treatment of substance abuse disorders may not, as a matter of course, seek out a thorough knowledge of their patients' drug use behaviors. Furthermore, currently available diagnostic criteria for substance abuse were developed and validated in youngand middle-aged samples and thus may not be appropriate for older adults. For example, some DSM IV criteria for substance dependence, such as tolerance and activity reduction, may not apply to this population (American Psychiatric Association, 2000; Patterson and Jeste, 1999). Aging may interfere with the body's ability to develop tolerance (Beresford et al, 1990); an older person, therefore, may demonstrate greater drug-related problems even though their patterns of use have remained stable (Adams and Cox, 1995; Fingerhood, 2000; National Institute on Alcohol Abuse and Alcoholism, 1998). Additionally, older adults, by dint of normal age-related changes, may become less active rendering detection of substance abuse problems more difficult (Fingerhood, 2000). Finally, warning signs of drug abuse (eg sleep problems, falls, memory problems) may be confused with or masked by concurrent illnesses, or attributed to normal aging.

The challenge of recognizing substance abuse disorders in older adults is compounded by the relative dearth of screening instruments designed specifically for older adults. Screens such as the Two-Item Conjoint Screen for alcohol and other drug use or dependence (Brown et al, 2001) and the Drug Abuse Screening Test have not been tested in this population. The Michigan Alcohol Screening Test (MAST) has been modified for use in older adults (MAST-G), and 
has been shown to have excellent sensitivity and good specificity; however, it is specific for alcohol abuse and has not been modified for detecting other drug use (Widlitz and Marin, 2002). The CAGE screening test has been modified to include other substances of abuse; has been tested in adults over the age of 60; also has been shown to have excellent sensitivity; specificity, however, is poor (Hinkin et al, 2001). Additional studies are needed to develop and test the validity of other drug abuse screening instruments in older adults.

\section{Treatment of Substance Abuse in Older Adults}

Significant increases in substance abuse among older adults, as may occur with the aging of the baby boomers, would increase the demand for relevant treatment services. Indeed, according to the 2003 Treatment Episodes Data Set, individuals aged 50 and older accounted for only $9 \%$ of treatment admissions. In contrast, in that same year, younger members of the baby boomer generation (aged 40-49) accounted for $25 \%$ of all treatment admissions (Substance Abuse and Mental Health Services Administration, 2004). Using regression modeling, with early onset drug use as a predictor, Gfroerer et al (2003) estimated that, due to a $50 \%$ increase in the number of older adults and a $70 \%$ increase in the rate of treatment need among older adults, the number of older adults in need of substance abuse treatment will increase from 1.7 million in 2000 and 2001 to 4.4 million in 2020 .

As baby boomers age, the types of drugs abused by older adults will likely change accordingly and facilitate a shift in the specific treatment needs of this population. Currently, older adults most commonly seek treatment for alcohol, stimulants other than amphetamine, tranquilizers, and sedatives. In contrast, young baby boomers most frequently seek treatment for cocaine suggesting that specific treatment needs may change over time (Substance Abuse and Mental Health Services Administration, 2004).

Once in treatment, older adults have short- and long-term outcomes equivalent to or better than those of younger adults, suggesting that the primary barrier to recovery is diagnosis and treatment entry (Fleming et al, 1999; Hser et al, 1997; Lemke and Moos, 2003a, b; Oslin et al, 2002; Satre et al, 2003, 2004). Older patients, however, may fare even better in programs tailored to older participants (Lemke and Moos, 2003a). Thus, treatment of substance abuse in older adults should reflect age-related brain changes as well as differences in the types of drugs abused in this population and in the settings in which these drugs are abused. Additionally, treatment outcomes for older adults may be further improved through the use of supportive and nonconfrontational approaches (Beresford et al, 1990), cognitive behavioral therapy (for those not cognitively disabled by drugs and/or disease) addressing negative affect, improving social support, and the use of specially trained providers (Schonfeld et al, 2000).

Pharmacological therapies should also be a critical component of drug treatment in older adults. Currently, a number of pharmacological therapies are available for the treatment of substance abuse including bupropion, nicotine replacement therapy, varenicline, naltrexone, methadone, and buprenorphine. None of these therapies, however, have been tested in older adults; thus, it is unclear if they retain their effectiveness or have unique adverse effects in this population.

\section{CONCLUSIONS}

It seems likely that in the coming years, substance abuse among older adults will be an increasing problem in the United States. As baby boomers advance into older age they, as a population, carry with them both a strong history of youth drug abuse and the view that drugs - whether for medical purposes or recreation - are a 'quick-fix' panacea for whatever ails you. The increased prevalence of comorbid conditions with age as well as age-related changes in drug metabolism and neurotransmitter systems mediating drugs' effects in the brain suggest, however, that even moderate drug abuse may pose greater risks to older adults. Unfortunately, the interaction between drug abuse and the aging process is poorly understood. Increased abuse of drugs in general as well as increased abuse of illicit drugs not traditionally prevalent among older adults would place greater and unique challenges on already strained healthcare and drug treatment resources. Meeting these challenges requires a better understanding of the scope and effects of drug abuse in this population. Research in relevant animal models would aid in elucidating the unique effects of drug abuse in older populations. Brain imaging studies across the lifespan would provide new insight into the long-term effects of drug abuse in older adults. Additionally, human clinical trials are critical to understanding issues of polypharmacy, medical comorbidity, increased risk of adverse effects, as well as age-related changes in pharmacokinetics and pharmacodynamics. Successfully addressing increased drug abuse among older adults would also require heightening awareness of this issue among both health-care professionals and the general public.

\section{ACKNOWLEDGEMENTS}

We gratefully acknowledge the assistance of Curtis Balmer in the preparation of this paper. His editorial and substantive comments significantly improved its content and clarity. The authors have no financial conflicts of interest that have the potential to bias this work.

\section{REFERENCES}

Adams KH, Pinborg LH, Svarer C, Hasselbalch SG, Holm S, Haugbol $S$ et al (2004). A database of [(18)F]-altanserin binding to $5-\mathrm{HT}(2 \mathrm{~A})$ receptors in normal volunteers: normative data and relationship to physiological and demographic variables. Neuroimage 21: 1105-1113.

Adams WL (1996). Alcohol use in retirement communities. J Am Geriatr Soc 44: 1082-1085.

Adams WL, Cox NS (1995). Epidemiology of problem drinking among elderly people. Int J Addict 30: 1693-1716.

Adams WL, Magruder-Habib K, Trued S, Broome HL (1992). Alcohol abuse in elderly emergency department patients. J Am Geriatr Soc 40: 1236-1240.

Administration on Aging (2003). Profile of Older Americans 2003. Available at: http://www.aoa.gov/prof/Statistics/profile/2003/ profiles2003.asp. Accessed October 20, 2004. 
Allen SJ, Benton JS, Goodhardt MJ, Haan EA, Sims NR, Smith CC et al (1983). Biochemical evidence of selective nerve cell changes in the normal ageing human and rat brain. J Neurochem 41: 256-265.

American Psychiatric Association (2000). Diagnostic and Statistical Manual of Mental Disorders DSM IV. American Psychiatric Association: Washington, DC.

Anderson TL, Levy JA (2003). Marginality among older injectors in today's illicit drug culture: assessing the impact of ageing. Addiction 98: 761-770.

Andersson A, Sundman I, Marcusson J (1992). Age stability of human brain 5 -HT terminals studied with $\left[{ }^{3} \mathrm{H}\right]$ paroxetine binding. Gerontology 38: 127-132.

Antonini A, Leenders KL (1993). Dopamine D2 receptors in normal human brain: effect of age measured by positron emission tomography (PET) and $\left[{ }^{11} \mathrm{C}\right]$-raclopride. Ann NY Acad Sci 695: 81-85.

Antonini A, Leenders KL, Reist H, Thomann R, Beer HF, Locher J (1993). Effect of age on D2 dopamine receptors in normal human brain measured by positron emission tomography and ${ }^{11}$ C-raclopride. Arch Neurol 50: 474-480.

Arranz B, Eriksson A, Mellerup E, Plenge P, Marcusson J (1993). Effect of aging in human cortical pre- and postsynaptic serotonin binding sites. Brain Res 620: 163-166.

Baeken C, D'haenen H, Flamen P, Mertens J, Terriere D, Chavatte $\mathrm{K}$ et al (1998). 123I-5-I-R91150, a new single-photon emission tomography ligand for 5-HT2A receptors: influence of age and gender in healthy subjects. Eur J Nucl Med 25: 1617-1622.

Baker D, Pryce G, Giovannoni G, Thompson AJ (2003). The therapeutic potential of cannabis. Lancet Neurol 2: 291-298.

Bannon MJ, Poosch MS, Xia Y, Goebel DJ, Cassin B, Kapatos G (1992). Dopamine transporter mRNA content in human substantia nigra decreases precipitously with age. Proc Natl Acad Sci USA 89: 7095-7099.

Bannon MJ, Whitty CJ (1997). Age-related and regional differences in dopamine transporter mRNA expression in human midbrain. Neurology 48: 969-977.

Barja G (2004). Free radicals and aging. Trends Neurosci 27: 595-600. Bartzokis G, Beckson M, Hance DB, Lu PH, Foster JA, Mintz J et al (1999a). Magnetic resonance imaging evidence of 'silent' cerebrovascular toxicity in cocaine dependence. Biol Psychiatry 45: 1203-1211.

Bartzokis G, Beckson M, Lu PH, Edwards N, Bridge P, Mintz J (2002). Brain maturation may be arrested in chronic cocaine addicts. Biol Psychiatry 51: 605-611.

Bartzokis G, Goldstein IB, Hance DB, Beckson M, Shapiro D, Lu $\mathrm{PH}$ et al (1999b). The incidence of T2-weighted MR imaging signal abnormalities in the brain of cocaine-dependent patients is age-related and region-specific. AJNR Am J Neuroradiol 20: 1628-1635.

Baum C, Kennedy DL, Knapp DE, Juergens JP, Faich GA (1988). Prescription drug use in 1984 and changes over time. Med Care 26: $105-114$

Beresford TP, Blow FC, Brower KJ (1990). Alcoholism in the elderly. Compr Ther 16: 38-43.

Blin J, Baron JC, Dubois B, Crouzel C, Fiorelli M, Attar-Levy D et al (1993). Loss of brain 5-HT2 receptors in Alzheimer's disease. In vivo assessment with positron emission tomography and $\left[{ }^{18} \mathrm{~F}\right]$ setoperone. Brain 116(Part 3): 497-510.

Bowyer JF, Gough B, Slikker Jr W, Lipe GW, Newport GD, Holson RR (1993). Effects of a cold environment or age on methamphetamine-induced dopamine release in the caudate putamen of female rats. Pharmacol Biochem Behav 44: 87-98.

Brown RL, Leonard T, Saunders LA, Papasouliotis O (2001). A twoitem conjoint screen for alcohol and other drug problems. $\mathrm{J} \mathrm{Am}$ Board Fam Pract 14: 95-106.

Capel WC, Peppers LG (1978). The aging addict: a longitudinal study of known abusers. Addict Dis 3: 389-403.
Cheetham SC, Crompton MR, Katona CL, Horton RW (1988). Brain 5-HT2 receptor binding sites in depressed suicide victims. Brain Res 443: 272-280.

Colliver JD, Compton WM, Gfroerer JC, Condon T (2006). Projecting drug use among aging baby boomers in 2020. Ann Epidemiol 16: 257-265.

Courchesne E, Chisum HJ, Townsend J, Cowles A, Covington J, Egaas B et al (2000). Normal brain development and aging: quantitative analysis at in vivo $\mathrm{MR}$ imaging in healthy volunteers. Radiology 216: 672-682.

Croxford JL (2003). Therapeutic potential of cannabinoids in CNS disease. CNS Drugs 17: 179-202.

de Rekeneire N, Visser M, Peila R, Nevitt MC, Cauley JA, Tylavsky FA et al (2003). Is a fall just a fall: correlates of falling in healthy older persons. The Health, Aging and Body Composition Study. J Am Geriatr Soc 51: 841-846.

Dealberto MJ, Mcavay GJ, Seeman T, Berkman L (1997). Psychotropic drug use and cognitive decline among older men and women. Int J Geriatr Psychiatry 12: 567-574.

Edwards I, Salib E (1999). 'Silent dependence syndrome' in old age ....! Int J Geriatr Psychiatry 14: 72-74.

Elwan O, Hassan AA, Abdel NM, Elwan F, Deif R, El Serafy O et al (1997). Brain aging in a sample of normal Egyptians cognition, education, addiction and smoking. J Neurol Sci 148: 79-86.

Fingerhood M (2000). Substance abuse in older people. J Am Geriatr Soc 48: 985-995.

Fleming MF, Manwell LB, Barry KL, Adams W, Stauffacher EA (1999). Brief physician advice for alcohol problems in older adults: a randomized community-based trial. J Fam Pract 48: 378-384.

Fowler CJ (2003). Plant-derived, synthetic and endogenous cannabinoids as neuroprotective agents. Non-psychoactive cannabinoids, 'entourage' compounds and inhibitors of $\mathrm{N}$-acyl ethanolamine breakdown as therapeutic strategies to avoid pyschotropic effects. Brain Res Brain Res Rev 41: 26-43.

Fowler JS, Volkow ND, Wang GJ, Pappas N, Logan J, MacGregor R et al (1996). Inhibition of monoamine oxidase B in the brains of smokers. Nature 379: 733-736.

Frank B (2000). An overview of heroin trends in New York City: past, present and future. Mt Sinai J Med 67: 340-346.

Frishman WH, Del Vecchio A, Sanal S, Ismail A (2003a). Cardiovascular manifestations of substance abuse part 1: cocaine. Heart Dis 5: 187-201.

Frishman WH, Del Vecchio A, Sanal S, Ismail A (2003b). Cardiovascular manifestations of substance abuse: part 2: alcohol, amphetamines, heroin, cannabis, and caffeine. Heart Dis 5: 253-271.

Gfroerer J, Penne M, Pemberton M, Folsom R (2003). Substance abuse treatment need among older adults in 2020: the impact of the aging baby-boom cohort. Drug Alcohol Depend 69: 127-135.

Giros B, Jaber M, Jones SR, Wightman RM, Caron MG (1996). Hyperlocomotion and indifference to cocaine and amphetamine in mice lacking the dopamine transporter. Nature 379: 606-612.

Grimble RF (2003). Inflammatory response in the elderly. Curr Opin Clin Nutr Metab Care 6: 21-29.

Gross-Isseroff R, Salama D, Israeli M, Biegon A (1990a). Autoradiographic analysis of age-dependent changes in serotonin 5-HT2 receptors of the human brain postmortem. Brain Res 519: 223-227.

Gross-Isseroff R, Salama D, Israeli M, Biegon A (1990b). Autoradiographic analysis of $\left[{ }^{3} \mathrm{H}\right]$ ketanserin binding in the human brain postmortem: effect of suicide. Brain Res 507: 208-215.

Grottick AJ, Higgins GA (2002). Assessing a vigilance decrement in aged rats: effects of pre-feeding, task manipulation, and psychostimulants. Psychopharmacology (Berlin) 164: 33-41.

Grundy RI (2002). The therapeutic potential of the cannabinoids in neuroprotection. Expert Opin Investig Drugs 11: 1365-1374. 
Grundy RI, Rabuffetti M, Beltramo M (2001). Cannabinoids and neuroprotection. Mol Neurobiol 24: 29-51.

Halliday R, Callaway E, Naylor H, Gratzinger P, Prael R (1986). The effects of stimulant drugs on information processing in elderly adults. J Gerontol 41: 748-757.

Hampson AJ, Grimaldi M, Axelrod J, Wink D (1998). Cannabidiol and (-)delta9-tetrahydrocannabinol are neuroprotective antioxidants. Proc Natl Acad Sci USA 95: 8268-8273.

Hampson AJ, Grimaldi M, Lolic M, Wink D, Rosenthal R, Axelrod J (2000). Neuroprotective antioxidants from marijuana. Ann NY Acad Sci 899: 274-282.

Hanlon JT, Schmader KE, Boult C, Artz MB, Gross CR, Fillenbaum $\mathrm{GG}$ et al (2002). Use of inappropriate prescription drugs by older people. J Am Geriatr Soc 50: 26-34.

Haycock JW, Becker L, Ang L, Furukawa Y, Hornykiewicz O, Kish SJ (2003). Marked disparity between age-related changes in dopamine and other presynaptic dopaminergic markers in human striatum. J Neurochem 87: 574-585.

Hesse S, Barthel H, Murai T, Muller U, Muller D, Seese A et al (2003). Is correction for age necessary in neuroimaging studies of the central serotonin transporter? Eur J Nucl Med Mol Imaging 30: 427-430.

Hicks P, Strong R, Schoolar JC, Samorajski T (1980). Aging alters amphetamine-induced stereotyped gnawing and neostriatal elimination of amphetamine in mice. Life Sci 27: 715-722.

Hinkin CH, Castellon SA, Dickson-Fuhrman E, Daum G, Jaffe J, Jarvik L (2001). Screening for drug and alcohol abuse among older adults using a modified version of the CAGE. Am J Addict 10: 319-326.

Hogan DB, Maxwell CJ, Fung TS, Ebly EM (2003). Prevalence and potential consequences of benzodiazepine use in senior citizens: results from the Canadian Study of Health and Aging. Can J Clin Pharmacol 10: 72-77.

Holroyd S, Duryee JJ (1997). Substance use disorders in a geriatric psychiatry outpatient clinic: prevalence and epidemiologic characteristics. J Nerv Ment Dis 185: 627-632.

Hser YI, Anglin MD, Grella C, Longshore D, Prendergast ML (1997). Drug treatment careers. A conceptual framework and existing research findings. J Subst Abuse Treat 14: 543-558.

Hser YI, Hoffman V, Grella CE, Anglin MD (2001). A 33-year follow-up of narcotics addicts. Arch Gen Psychiatry 58: 503-508.

Imam SZ, Ali SF (2001). Aging increases the susceptiblity to methamphetamine-induced dopaminergic neurotoxicity in rats: correlation with peroxynitrite production and hyperthermia. J Neurochem 78: 952-959.

Inoue M, Suhara T, Sudo Y, Okubo Y, Yasuno F, Kishimoto T et al (2001). Age-related reduction of extrastriatal dopamine D2 receptor measured by PET. Life Sci 69: 1079-1084.

Ishikawa T, Dhawan V, Kazumata K, Chaly T, Mandel F, Neumeyer $\mathrm{J}$ et al (1996). Comparative nigrostriatal dopaminergic imaging with iodine-123-beta CIT-FP/SPECT and fluorine-18-FDOPA/ PET. J Nucl Med 37: 1760-1765.

Iyo M, Yamasaki T (1993). The detection of age-related decrease of dopamine D1, D2 and serotonin 5-HT2 receptors in living human brain. Prog Neuropsychopharmacol Biol Psychiatry 17: 415-421.

Jernigan TL, Archibald SL, Fennema-Notestine C, Gamst AC, Stout JC, Bonner J et al (2001). Effects of age on tissues and regions of the cerebrum and cerebellum. Neurobiol Aging 22: 581-594.

Jha SH, Knapp CM, Kornetsky C (2004). Effects of morphine on brain-stimulation reward thresholds in young and aged rats. Pharmacol Biochem Behav 79: 483-490.

Jinks MJ, Raschko RR (1990). A profile of alcohol and prescription drug abuse in a high-risk community-based elderly population. DICP 24: 971-975.

Johnson KH, Bazargan M, Cherpitel CJ (2001). Alcohol, tobacco, and drug use and the onset of type 2 diabetes among inner-city minority patients. J Am Board Fam Pract 14: 430-436.
Johnson RA, Gerstein DR (1998). Initiation of use of alcohol, cigarettes, marijuana, cocaine, and other substances in US birth cohorts since 1919. Am J Public Health 88: 27-33.

Kaasinen V, Kemppainen N, Nagren K, Helenius H, Kurki T, Rinne JO (2002). Age-related loss of extrastriatal dopamine D(2)-like receptors in women. J Neurochem 81: 1005-1010.

Kaasinen V, Vilkman H, Hietala J, Nagren K, Helenius H, Olsson H et al (2000). Age-related dopamine D2/D3 receptor loss in extrastriatal regions of the human brain. Neurobiol Aging 21: 683-688.

Kaiser Family Foundation (2003). Impact of Direct-to-Consumer Advertising on Prescription Drug Spending. Available at: http:// www.kff.org/rxdrugs/6084-index.cfm. Accessed March 3, 2006.

Kales HC, Blow FC, Welsh DE, Mellow AM (2004). Herbal products and other supplements: use by elderly veterans with depression and dementia and their caregivers. J Geriatr Psychiatry Neurol 17: 25-31.

Kazumata K, Dhawan V, Chaly T, Antonini A, Margouleff C, Belakhlef A et al (1998). Dopamine transporter imaging with fluorine-18-FPCIT and PET. J Nucl Med 39: 1521-1530.

Kemppainen N, Marjamaki P, Roytta M, Rinne JO (2001). Different pattern of reduction of striatal dopamine reuptake sites in Alzheimer's disease and ageing. J Neural Transm 108: 827-836.

Kilbey MM, Ellinwood Jr EH (1977). The effect of age-related factors on behavior induced by cocaine. Life Sci 20: 1847-1854.

Kilbey MM, Ellinwood Jr EH, Gonzalez LP, Cooper RL (1980). Differential dopaminergic function in young and old female rats as measured by three behaviors. Commun Psychopharmacol 4: 1-9.

Knapp CM, Jha SH, Kornetsky C (2004). Increased sensitization to morphine-induced oral stereotypy in aged rats. Pharmacol Biochem Behav 79: 491-497.

Kornetsky C (2004). A review of pain and analgesia in older patients. Geriat Aging 7: 61-64.

Kuikka JT, Tammela L, Bergstrom KA, Karhunen L, Uusitupa M, Tiihonen J (2001). Effects of ageing on serotonin transporters in healthy females. Eur J Nucl Med 28: 911-913.

Lastres-Becker I, Hansen HH, Berrendero F, De Miguel R, PerezRosado A, Manzanares J et al (2002). Alleviation of motor hyperactivity and neurochemical deficits by endocannabinoid uptake inhibition in a rat model of Huntington's disease. Synapse 44: 23-35.

Lemke S, Moos RH (2003a). Outcomes at 1 and 5 years for older patients with alcohol use disorders. J Subst Abuse Treat 24 43-50.

Lemke S, Moos RH (2003b). Treatment and outcomes of older patients with alcohol use disorders in community residential programs. J Stud Alcohol 64: 219-226.

Marcusson J, Oreland L, Winblad B (1984a). Effect of age on human brain serotonin (S-1) binding sites. J Neurochem 43: 1699-1705.

Marcusson JO, Alafuzoff I, Backstrom IT, Ericson E, Gottfries CG, Winblad B (1987). 5-Hydroxytryptamine-sensitive $\left[{ }^{3} \mathrm{H}\right]$ imipramine binding of protein nature in the human brain. II. Effect of normal aging and dementia disorders. Brain Res 425: 137-145.

Marcusson JO, Morgan DG, Winblad B, Finch CE (1984b). Serotonin-2 binding sites in human frontal cortex and hippocampus. Selective loss of S-2A sites with age. Brain Res 311: 51-56.

McGeer PL, McGeer EG, Suzuki JS (1977). Aging and extrapyramidal function. Arch Neurol 34: 33-35.

Menninger JA (2002). Assessment and treatment of alcoholism and substance-related disorders in the elderly. Bull Menninger Clin 66: $166-183$.

Miller DB, O'Callaghan JP, Ali SF (2000). Age as a susceptibility factor in the striatal dopaminergic neurotoxicity observed in the mouse following substituted amphetamine exposure. Ann NY Acad Sci 914: 194-207. 
Miller NS, Belkin BM, Gold MS (1991). Alcohol and drug dependence among the elderly: epidemiology, diagnosis, and treatment. Compr Psychiatry 32: 153-165.

Mozley PD, Acton PD, Barraclough ED, Plossl K, Gur RC, Alavi A et al (1999). Effects of age on dopamine transporters in healthy humans. J Nucl Med 40: 1812-1817.

Mozley PD, Kim HJ, Gur RC, Tatsch K, Muenz LR, McElgin WT et al (1996). Iodine-123-IPT SPECT imaging of CNS dopamine transporters: nonlinear effects of normal aging on striatal uptake values. J Nucl Med 37: 1965-1970.

Mukherjee J, Christian BT, Dunigan KA, Shi B, Narayanan TK, Satter $\mathrm{M}$ et al (2002). Brain imaging of ${ }^{18} \mathrm{~F}$-fallypride in normal volunteers: blood analysis, distribution, test-retest studies, and preliminary assessment of sensitivity to aging effects on dopamine D-2/D-3 receptors. Synapse 46: 170-188.

National Center on Addiction and Substance Abuse (CASA) (2005). Under the Counter: The Diversion and Abuse of Controlled Prescription Drugs in the US. Available at: http:// www.casacolumbia.org/absolutenm/articlefiles/380-under_the_ counter_diversion.pdf. Accessed March 31, 2006.

National Center on Addiction and Substance Abuse at Columbia University (CASA) (2000). Missed Opportunity: National Survey of Primary Care Physicians and Patients on Substance Abuse. Available at: http://www.casacolumbia.org/Absolutenm/articlefiles/29109.pdf. Accessed March 3, 2006.

National Center on Addiction and Substance Abuse at Columbia University (CASA) (1998). Under the Rug: Substance Abuse and The Mature Woman. Available at: http://www.casacolumbia.org/ Absolutenm/articlefiles/Under_the_Rug_6_15_98.pdf. Accessed May 18, 2004.

National Institute on Alcohol Abuse and Alcoholism (1998). Alcohol Alert No. 40. Available at: http://www.niaaa.nih.gov/ publications/aa40.htm. Accessed March 23, 2004.

Noble RE (2003). Drug therapy in the elderly. Metabolism 52: 27-30.

Olney JW, Wozniak DF, Farber NB (1997). Excitotoxic neurodegeneration in Alzheimer disease. New hypothesis and new therapeutic strategies. Arch Neurol 54: 1234-1240.

Oslin DW, Pettinati H, Volpicelli JR (2002). Alcoholism treatment adherence: older age predicts better adherence and drinking outcomes. Am J Geriatr Psychiatry 10: 740-747.

Panikashvili D, Simeonidou C, Ben Shabat S, Hanus L, Breuer A, Mechoulam $\mathrm{R}$ et al (2001). An endogenous cannabinoid (2-AG) is neuroprotective after brain injury. Nature 413: 527-531.

Paterniti S, Dufouil C, Alperovitch A (2002). Long-term benzodiazepine use and cognitive decline in the elderly: the Epidemiology of Vascular Aging Study. J Clin Psychopharmacol 22: 285-293.

Patterson TL, Jeste DV (1999). The potential impact of the babyboom generation on substance abuse among elderly persons. Psychiatr Serv 50: 1184-1188.

Perneger TV, Klag MJ, Whelton PK (2001). Recreational drug use: a neglected risk factor for end-stage renal disease. Am J Kidney Dis 38: $49-56$.

Pirker W, Asenbaum S, Hauk M, Kandlhofer S, Tauscher J, Willeit $M$ et al (2000). Imaging serotonin and dopamine transporters with 123I-beta-CIT SPECT: binding kinetics and effects of normal aging. J Nucl Med 41: 36-44.

Quik M (2004). Smoking, nicotine and Parkinson's disease. Trends Neurosci 27: 561-568.

Rathore SS, Mehta SS, Boyko Jr WL, Schulman KA (1998). Prescription medication use in older Americans: a national report card on prescribing. Fam Med 30: 733-739.

Reeves S, Bench C, Howard R (2002). Ageing and the nigrostriatal dopaminergic system. Int J Geriatr Psychiatry 17: 359-370.

Rinne JO, Lonnberg P, Marjamaki P (1990). Age-dependent decline in human brain dopamine D1 and D2 receptors. Brain Res 508: 349-352.
Rosen D (2004). Factors associated with illegal drug use among older methadone clients. Gerontologist 44: 543-547.

Rosenberg H (1995). The elderly and the use of illicit drugs: sociological and epidemiological considerations. Int J Addict 30: 1925-1951.

Sarkisian CA, Liu H, Gutierrez PR, Seeley DG, Cummings SR, Mangione CM (2000). Modifiable risk factors predict functional decline among older women: a prospectively validated clinical prediction tool. The Study of Osteoporotic Fractures Research Group. J Am Geriatr Soc 48: 170-178.

Satre DD, Mertens J, Arean PA, Weisner C (2003). Contrasting outcomes of older versus middle-aged and younger adult chemical dependency patients in a managed care program. J Stud Alcohol 64: 520-530.

Satre DD, Mertens JR, Arean PA, Weisner C (2004). Five-year alcohol and drug treatment outcomes of older adults versus middle-aged and younger adults in a managed care program. Addiction 99: 1286-1297.

Schlaerth KR, Splawn RG, Ong J, Smith SD (2004). Change in the pattern of illegal drug use in an inner city population over 50: an observational study. J Addict Dis 23: 95-107.

Schonfeld L, Dupree LW, Dickson-Euhrmann E, Royer CM, McDermott CH, Rosansky JS et al (2000). Cognitive-behavioral treatment of older veterans with substance abuse problems. J Geriatr Psychiatry Neurol 13: 124-129.

Segovia G, Porras A, Del Arco A, Mora F (2001). Glutamatergic neurotransmission in aging: a critical perspective. Mech Ageing Dev 122: 1-29.

Severson JA, Marcusson J, Winblad B, Finch CE (1982). Agecorrelated loss of dopaminergic binding sites in human basal ganglia. J Neurochem 39: 1623-1631.

Severson JA, Marcusson JO, Osterburg HH, Finch CE, Winblad B (1985). Elevated density of $\left[{ }^{3} \mathrm{H}\right]$ imipramine binding in aged human brain. J Neurochem 45: 1382-1389.

Smith RC, Leelavathi DE, Lauritzen AM (1978). Behavioral effects of dopamine agonists increase with age. Commun Psychopharmacol 2: 39-43.

Sowell ER, Peterson BS, Thompson PM, Welcome SE, Henkenius AL, Toga AW (2003). Mapping cortical change across the human life span. Nat Neurosci 6: 309-315.

Sparks DL (1989). Aging and Alzheimer's disease. Altered cortical serotonergic binding. Arch Neurol 46: 138-140.

Stoehr GP, Ganguli M, Seaberg EC, Echement DA, Belle S (1997). Over-the-counter medication use in an older rural community: the MoVIES Project. J Am Geriatr Soc 45: 158-165.

Substance Abuse and Mental Health Services (2006). Results from the 2005 National Survey on Drug Use and Health: National Findings. Available at: http://www.oas.samhsa.gov/NSDUH/ 2k5NSDUH/2k5results.htm\#2.4. Accessed January 5, 2007.

Substance Abuse and Mental Health Services Administration (2002). Detailed Emergency Department Tables From DAWN: 2002. Available at: http://dawninfo.samhsa.gov/old dawn/ pubs_94_02/pickatable/2001/2.8.0.xls. Accessed March 31, 2006.

Substance Abuse and Mental Health Services Administration (2004). Treatment Episode Data Set 2003. Available at: http:// wwwdasis.samhsa.gov/teds03/tedsdischweb2k3.pdf. Accessed May 5, 2006.

Suhara T, Fukuda H, Inoue O, Itoh T, Suzuki K, Yamasaki T et al (1991). Age-related changes in human D1 dopamine receptors measured by positron emission tomography. Psychopharmacology (Berlin) 103: 41-45.

Teuchert-Noodt G, Dawirs RR (1991). Age-related toxicity in prefrontal cortex and caudate-putamen complex of gerbils (Meriones unguiculatus) after a single dose of methamphetamine. Neuropharmacology 30: 733-743.

Truex LL, Schmidt MJ (1980). H-amphetamine concentrations in the brains of young and aged rats: implications for assessment of drug effects in aged animals. Neurobiol Aging 1: 93-95. 
Turnheim K (2003). When drug therapy gets old: pharmacokinetics and pharmacodynamics in the elderly. Exp Gerontol 38: 843-853.

van Dyck $\mathrm{CH}$, Malison RT, Seibyl JP, Laruelle M, Klumpp H, Zoghbi SS et al (2000). Age-related decline in central serotonin transporter availability with [(123)I]beta-CIT SPECT. Neurobiol Aging 21: 497-501.

van Dyck CH, Seibyl JP, Malison RT, Laruelle M, Wallace E, Zoghbi SS et al (1995). Age-related decline in striatal dopamine transporter binding with iodine-123-beta-CITSPECT. J Nucl Med 36: 1175-1181.

van Dyck $\mathrm{CH}$, Seibyl JP, Malison RT, Laruelle M, Zoghbi SS, Baldwin RM et al (2002). Age-related decline in dopamine transporters: analysis of striatal subregions, nonlinear effects, and hemispheric asymmetries. Am J Geriatr Psychiatry 10: 36-43.

Villares JC, Stavale JN (2001). Age-related changes in the Nmethyl-D-aspartate receptor binding sites within the human basal ganglia. Exp Neurol 171: 391-404.

Volkow ND, Fowler JS, Wang GJ, Hitzemann R, Logan J, Schlyer DJ et al (1993). Decreased dopamine D2 receptor availability is associated with reduced frontal metabolism in cocaine abusers. Synapse 14: 169-177.

Volkow ND, Fowler JS, Wang GJ, Logan J, Schlyer D, MacGregor R et al (1994). Decreased dopamine transporters with age in health human subjects. Ann Neurol 36: 237-239.

Volkow ND, Gur RC, Wang GJ, Fowler JS, Moberg PJ, Ding YS et al (1998a). Association between decline in brain dopamine activity with age and cognitive and motor impairment in healthy individuals. Am J Psychiatry 155: 344-349.

Volkow ND, Logan J, Fowler JS, Wang GJ, Gur RC, Wong C et al (2000). Association between age-related decline in brain dopamine activity and impairment in frontal and cingulate metabolism. Am J Psychiatry 157: 75-80.

Volkow ND, Wang G, Fowler JS, Logan J, Gerasimov M, Maynard L et al (2001). Therapeutic doses of oral methylphenidate significantly increase extracellular dopamine in the human brain. J Neurosci 21: RC121.

Volkow ND, Wang GJ, Fowler JS, Ding YS, Gur RC, Gatley J et al (1998b). Parallel loss of presynaptic and postsynaptic dopamine markers in normal aging. Ann Neurol 44: 143-147.

Volkow ND, Wang GJ, Fowler JS, Logan J, Gatley SJ, MacGregor RR et al (1996). Measuring age-related changes in dopamine D2 receptors with ${ }^{11} \mathrm{C}$-raclopride and ${ }^{18} \mathrm{~F}-\mathrm{N}$-methylspiroperidol. Psychiatry Res 67: 11-16.

Vupputuri S, Batuman V, Muntner P, Bazzano LA, Lefante JJ, Whelton PK et al (2004). The risk for mild kidney function decline associated with illicit drug use among hypertensive men. Am J Kidney Dis 43: 629-635.

Wang GJ, Volkow ND, Fowler JS, Fischman M, Foltin R, Abumrad NN et al (1997). Cocaine abusers do not show loss of dopamine transporters with age. Life Sci 61: 1059-1065.

Wang GJ, Volkow ND, Fowler JS, Logan J, Gur R, Netusil N et al (1996). Age associated decrements in dopamine D2 receptors in thalamus and in temporal insula of human subjects. Life Sci 59: L31-L35.

Wang L, Liu J, Harvey-White J, Zimmer A, Kunos G (2003). Endocannabinoid signaling via cannabinoid receptor 1 is involved in ethanol preference and its age-dependent decline in mice. Proc Natl Acad Sci USA 100: 1393-1398.

Wang Y, Chan GL, Holden JE, Dobko T, Mak E, Schulzer M et al (1998). Age-dependent decline of dopamine D1 receptors in human brain: a PET study. Synapse 30: 56-61.

Warenycia MW, McKenzie GM (1989). Decreases in behavioral and striatal neuronal responses to dexamphetamine with aging. Pharmacol Biochem Behav 33: 489-491.

Warner EA, Greene GS, Buchsbaum MS, Cooper DS, Robinson BE (1998). Diabetic ketoacidosis associated with cocaine use. Arch Intern Med 158: 1799-1802.

Weintraub E, Weintraub D, Dixon L, Delahanty J, Gandhi D, Cohen A et al (2002). Geriatric patients on a substance abuse consultation service. Am J Geriatr Psychiatry 10: 337-342.

Whitcup SM, Miller F (1987). Unrecognized drug dependence in psychiatrically hospitalized elderly patients. J Am Geriatr Soc 35: 297-301.

Widlitz M, Marin DB (2002). Substance abuse in older adults. An overview. Geriatrics 57: 29-34.

Winick C (1962). Maturing out of narcotic addiction. Bull Narc 14: $1-7$.

Wong DF, Young D, Wilson PD, Meltzer CC, Gjedde A (1997). Quantification of neuroreceptors in the living human brain: III. D2-like dopamine receptors: theory, validation, and changes during normal aging. J Cereb Blood Flow Metab 17: 316-330.

Yamamoto M, Suhara T, Okubo Y, Ichimiya T, Sudo Y, Inoue M et al (2002). Age-related decline of serotonin transporters in living human brain of healthy males. Life Sci 71: 751-757. 